\title{
A Qualitative and Quantitative Assay to Study DNA/Drug Interaction Based on Sequence Selective Inhibition of Restriction Endonucleases
}

\author{
Syed A Hassan ${ }^{1 *}$, Lata Chauhan ${ }^{2}$, Ritu Barthwal ${ }^{2}$ and Aparna Dixit ${ }^{3}$ \\ ${ }_{1}^{1}$ Faculty of Computing and Information Technology, King Abdul Aziz University, Rabigh-21911, Saudi Arabia, \\ ${ }^{2}$ Department of Biotechnology, Indian Institute of Technology Roorkee, Roorkee-247667, Uttaranchal, ${ }^{3}$ School of \\ Biotechnology, Jawaharlal Nehru University, New Delhi-110067, India
}

\begin{abstract}
Purpose: To explore the use of restriction inhibition assay (RIA) to study the binding specificity of some anticancer drugs.

Methods: A 448 bp DNA fragment derived from pBCKS+ plasmid (harboring the polylinker region with multiple restriction endonuclease sites) was used as a template for sequence selective inhibition of the test drugs. The template was incubated with different concentrations of anticancer drugs (adriamycin, daunomycin, mitoxantrone, distamycin-A, berberine and palmatine) prior to digestion with restriction endonucleases - HindIII, EcoRI and EcoRV.

Results: Mitoxantrone, adriamycin and daunomycin showed specificity for Hind/ll restriction site (5'AAGCTT-3') at 220, 100 and $100 \mu \mathrm{M}$ concentration, respectively. Conversely, distamycin-A showed an affinity for EcoRI (5'-AAATGC-3') restriction sites at a concentration of $10 \mu \mathrm{M}$. No binding was observed for berberine and palmatine at a maximum concentration of $2 \mathrm{mM}$ at HindlII, EcoRI and EcoRV restriction sites, respectively.

Conclusion: The inhibition of endonucleases by mitoxantrone, adriamycin, daunomycin, distamycin- $A$, provides direct evidence of the co-existence of concentration and sequence specificity for drug-DNA interaction as well as the need to explore the possible use of RIA for demonstrating the binding specificity of anticancer drugs.
\end{abstract}

Keywords: Restriction endonucleases, Restriction sites, Anticancer drugs, Restriction inhibition assay (RIA), Binding specificity. 


\section{INTRODUCTION}

Interaction of some anti-tumor agents with DNA has been the subject of intensive research. In this regard, considerable amount of effort has been made to elucidate the molecular basis of action of several drugs such as adriamycin, daunomycin, distamycinA, mitoxantrone, berberine and palmatine, which are known to bind to DNA. These drugs have good anti-tumor activity and this activity has been correlated to sequence specific binding to DNA. Sequence specificity of these drugs has been attempted using DNA foot printing, in vitro transcription assay, restriction inhibition assay, absorption spectroscopy, fluorescence, circular dichroism spectroscopy, Nuclear Magnetic Resonance (NMR) spectroscopy and $X$ ray crystallography. DNase foot printing experiments have shown preference for $\mathrm{CpG}$, CpA, TpA sites in DNA with mitoxantrone [1]. Adriamycin and daunomycin have shown affinity for $\mathrm{CpA}$ rich sequences [2]. Transcriptional inhibition assay have shown preferences for 5'-(A/T) CA and 5'-(A/T)CG sites on DNA for mitoxantrone [3] and 5'-TCA for adriamycin and GC flanked at 5 ' by AT sequences for daunomycin [4]. In this context restriction inhibition assay showed more specificity for CA- than GC-rich sequence for adriamycin and more affinity towards GC than AT rich sequence for daunomycin [5], distamycin-A showed more specificity for AT rich sequence [6].

The structures of some drugs complexed with specific oligonucleotide have been studied in recent times by X-ray and NMR. The structure of adriamycin complexed with DNA and studied by X-ray [7] and NMR [8] have shown that in these complexes the chromophore is intercalated at CpG, while in the case of daunomycin $[9,10]]$, it was noticed that daunomycin intercalates in the $d(C p G)$ and $d(T p G)$ sequences respectively. Structural studies of distamycin $A$ with sequences such as d (CGCGAATTCGCG $)_{2}$ [11] and d(CGCAAATTTGCG $)_{2}$ using NMR [12] and X-ray [13] respectively, have shown that distamycin-A prefers AT-rich sequence in the minor groove of DNA. In this context, we embarked on experiments to detect the sequence specificity of berberine, palmatine and mitoxantrone whose sequence specific interaction with HindlII (5'-AAGCTT-3'), EcoRI (5'-AAATGC-3') and EcoRV (5'AATAGC-3') binding sites remained to be explored by restriction inhibition assay. We have also confirmed daunomycin, adriamycin and distamycin-Sequence specificity using Restriction Inhibition Assay (RIA) in conjunction with data from available literature was adopted in which the protocol was standardized the protocol and used for our experimental work.

\section{EXPERIMENTAL}

\section{Drugs and chemicals}

Adriamycin, daunomycin, distamycin-A, mitoxantrone, berberine and palmatine were purchased from Sigma Aldrich Co. USA. Restriction endonucleases Pvull, HindIII, EcoRI and EcoRV supplied with NEB $(10 \mathrm{x})$ restriction buffer (100 mM Tris- $\mathrm{HCl} \mathrm{pH} 7.5,1$ mM EDTA, 100 mM magnesium acetate, 500 $\mathrm{mM}$ potassium acetate) were purchased from New England Biolab, UK. Stock solutions of distamycin-A $(100 \mu \mathrm{M})$, mitoxantrone $(1 \mathrm{mM})$, adriamycin $(100 \mathrm{mM})$, daunomycin $(1 \mathrm{mM})$, berberine $(100 \mathrm{mM})$ and palmatine $(100 \mathrm{mM})$ were prepared by dissolving each initially in minimum autoclaved milli-Q water before making up to volume with the same. All solutions were stored at $4{ }^{\circ} \mathrm{C}$.

\section{DNA fragment for restriction inhibition assay (RIA)}

The $448 \mathrm{bp}$ fragment was obtained from $\mathrm{pBCKS}^{+}$DNA by the following procedure. The $\mathrm{pBCKS}^{+}$DNA was transformed into $E$. coli. Cell bearing plasmids were grown and amplified with chloramphenicol $(20 \mu \mathrm{g} / \mathrm{ml})$, and the DNA was isolated and purified by alkaline lysis method [14]. The $\mathrm{pBCKS}^{+}$ plasmid DNA samples were stored at $-20{ }^{\circ} \mathrm{C}$ in Tris $\mathrm{HCl}$ buffer (10 mM Tris- $\mathrm{HCl}, \mathrm{pH} 8.0$ ) containing $1 \mathrm{mM}$ EDTA. The $448 \mathrm{bp}$ DNA 
fragment was derived from pBCKS+ plasmid (harboring the polylinker region with multiple restriction endonuclease sites) by restricting with Pvull restriction enzyme and eluting the 448 bp fragment by gel elution and then purifying it further by phenol, chloroform and isoamyl alcohol method and ethanol precipitation. The $448 \mathrm{bp}$ fragment was stored at $-20{ }^{\circ} \mathrm{C}$ in Tris $\mathrm{HCl}$ buffer $(10 \mathrm{mM}$ Tris $\mathrm{HCl}, \mathrm{pH}$ 8.0) containing $1 \mathrm{mM}$ EDTA.

\section{Binding studies}

The anti-tumor drug-DNA complexes were prepared by preincubating $4 \mu \mathrm{l}$ (300 $\mathrm{ng}$ ) of the 448 bp DNA fragment with a range of concentration of the drugs in NEB restriction buffer $(1 \mathrm{x})$ for $30 \mathrm{~min}$ at $37{ }^{\circ} \mathrm{C}$. The restriction digestion was carried out by incubating with EcoRI, EcoRV and HindlII respectively for a further $1 \mathrm{~h}$ at $37^{\circ} \mathrm{C}$ in a final volume of $20 \mu \mathrm{l}$. A control setup with the DNA along with each restriction enzyme alone was kept to analyze the results of the restriction inhibition assay. Each digestion was stopped by incubation for $20 \mathrm{~min}$ at 65 ${ }^{\circ} \mathrm{C}$ followed by $10 \mathrm{~min}$ at $4{ }^{\circ} \mathrm{C}$. A $20 \mu \mathrm{l}$ of the digestion mixture was added with $5 \mu$ of $6 \mathrm{x}$ DNA loading dye $(0.25 \%$ bromophenol blue and $30 \%$ glycerol) and loaded on to $2 \%$ horizontal agarose gel in case of 448 bp DNA fragment which was run in Tris-acetate EDTA buffer $(40 \mathrm{mM}$ Tris base, $\mathrm{pH} 8.0,18 \mathrm{mM}$ glacial acetic acid and $1 \mathrm{mM}$ EDTA) at $100 \mathrm{~V}$ for $2 \mathrm{~h}$. The gel was exposed to $220 \mathrm{~nm}$ near UV region spectrum and then the DNA bands were visualized and analyzed for drug-DNA interaction studies.

\section{RESULTS}

Binding of distamycin-A, adriamycin and daunomycin to the EcoRI (5'-AAATGC-3') and HindIII (5'-AAGCTT-3') restriction sequence

The results on the detection of binding of Distamycin-A, Adriamycin and Daunomycin to DNA by restriction inhibition assay (RIA).are shown in Fig 1 - 3. We first produced a 448 bp target double stranded DNA fragment consisting of the polylinker region from the $\mathrm{pBCKS}^{+}$plasmid DNA. Second, we allowed distamycin-A, adriamycin and daunomycin to bind to the 448 bp double stranded DNA.

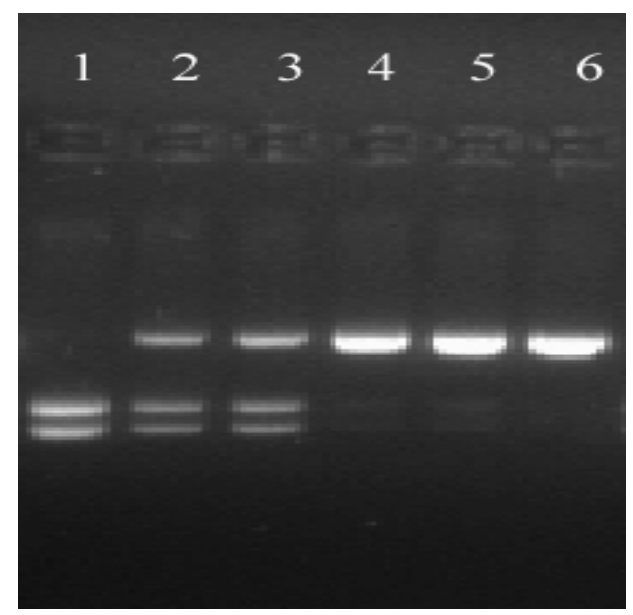

Figure 1: Agarose gel (2\%) showing inhibition of EcoRl cleavage of $448 \mathrm{bp}$ fragments of $\mathrm{pBCKS}^{+}$ by distamycin $\mathrm{A}$. Lane 1: Control complete digest of 448 bp DNA fragment by EcoRl; Lanes 2-7: distamycin A-448 bp complex digested by EcoRI with distamycin-A concentrations of 2, 4, 6, 8, 10 and $12 \mu \mathrm{M}$, respectively.

In Fig 1 , the binding of distamycin-A to the target, 448 bp double stranded DNA, was studied at different drug concentrations ranging from 2 to $12 \mu \mathrm{M}$. The experiment shows a gradual decrease in intensity of digested fragment in a concentration dependent manner which reaches complete inhibition of EcoRI at $10 \mu \mathrm{M}$ concentration by distamycin-A, showing specificity for AT sequence. Similarly, Figs 2 and 3 demonstrate that adriamycin and daunomycin studied at different drug concentrations inhibited the restriction activity of HindllI in a concentration dependent manner and showed specificity for GC containing sequences. The experimental results demonstrate that both adriamycin and daunomycin show complete inhibition of HindIII at $100 \mu \mathrm{M}$ concentration. 


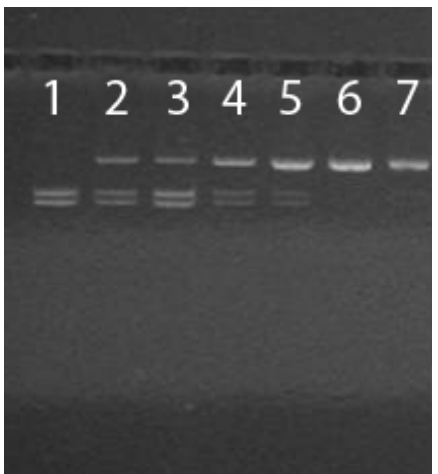

Figure 2: Agarose gel (2\%) showing inhibition of HindlII cleavage of 448 bp fragments of $\mathrm{pBCKS}^{+}$ by adriamycin. Lane 1: Control complete digest of 448 bp DNA fragment by HindIII; Lanes 2-6: adriamycin-448 bp complex digested by EcoRI with adriamycin concentrations of $20,40,60,80$ and $100 \mu \mathrm{M}$, respectively.

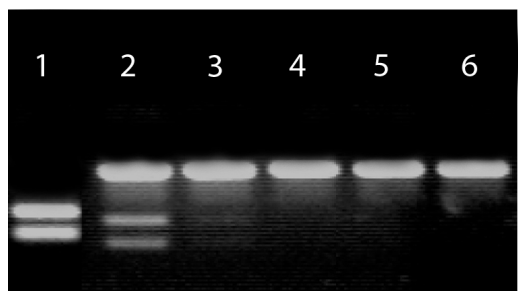

Figure 3: Agarose gel (2\%) showing inhibition of HindIII cleavage of $448 \mathrm{bp}$ fragments of $\mathrm{pBCKS}^{+}$ by daunomycin. Lane 1: Control complete digest of 448 bp DNA fragment by HindIII; Lanes 2-6: daunomycin-448 bp complex digested by HindIII with daunomycin concentrations of $80,90,100$, 110 and $120 \mu \mathrm{M}$, respectively.

\section{Detection of binding of mitoxantrone to the HindIII restriction sequence (5'- AAGCTT-3').}

To determine whether binding of mitoxantrone to DNA is detectable by restriction inhibition assay, the experiment shown in Figures 1-3 was repeated using mitoxantone. Figure 4 shows the experiment conducted to demonstrate the binding specificity of mitoxantrone for Hindlll restriction sequence (5'-AAGCTT-3'). The drug was studied at different concentrations ranging from 200 to $240 \mu \mathrm{M}$. An inhibition of HindIII, in a concentration dependent manner was observed for mitoxantrone and eventually at $220 \mu \mathrm{M}$ a complete inhibition was seen. The result clearly shows sequence specific interaction of mitoxantrone with HindIII restriction sequence, 5'-AAGCTT-3'.

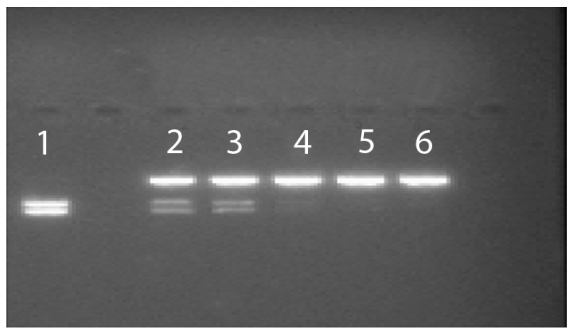

Figure 4: Agarose gel (2\%) showing inhibition of HindIII cleavage of 448 bp fragments of $\mathrm{pBCKS}^{+}$ by mitoxantrone. Lane 1: Control complete digest of 448 bp DNA fragment by HindlII; Lanes 2-6: mitoxantrone-448 bp complex digested by HindlII with mitoxantrone concentrations of 200, 210, 220, 230 and $240 \mu \mathrm{M}$, respectively.

\section{Detecting binding of palmatine and berberine to the EcoRI (5'-AAATGC-3') and EcoRV (5'-AATAGC-3') restriction sequences.}

The assay was carried to study the binding specificity of berberine and palmatine. Figure 7 shows that under these experimental conditions, berberine and palmatine did not bind to both ECORI (5'-AAGCTT-3') and EcoRV (5'-AATAGC-3') restriction sequences. The study was carried out using drugs at different concentrations, but even at $2 \mathrm{mM}$ concentration no inhibition of both EcoRI and EcoRV was observed.

\section{DISCUSSION}

The principle of RIA assay is based upon the ability of different anti-tumor drugs to inhibit the cleavage activity of restriction endonucleases HindIII, EcoRI and EcoRV. In the gel assays of distamycin-A, adriamycin and daunomycin, a gradual decrease in the intensity of the digested fragment was observed and finally a $100 \%$ inhibition of restriction was observed. It was observed that distamycin inhibits the restriction digestion of EcoRI at $10 \mu \mathrm{M}$ concentration 
and shows its sequence specificity towards AT site present in EcoRI. This result is in accordance with earlier studies [6]. They suggested that distamycin binds to AT rich sequences using restriction inhibition assay at $100 \mu \mathrm{M}$. It was then further proved by structural studies that distamycin binds to AT base pair by minor groove binding [11-13].

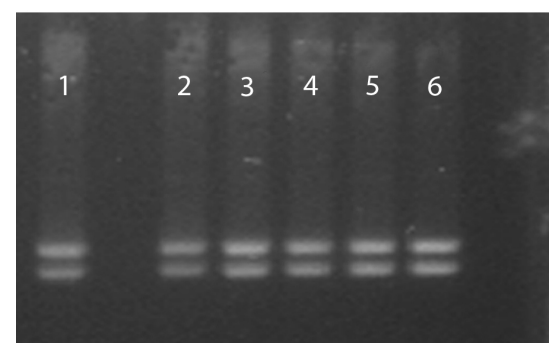

Figure 5: Agarose gel (2\%) showing inhibition of EcoRI and EcoRV cleavage of 448 bp fragments of $\mathrm{pBCKS}^{+}$by berberine and palmatine. Lane 1: Control complete digest of 448 bp DNA fragment by EcoRl; Lane 2: berberine-448 bp complex digested by EcoRI with berberine concentration of $2 \mathrm{mM}$; Lane 3: palmatine-448bp fragment complexes digested by EcoRI with palmatine concentration of $2 \mathrm{mM}$; Lane 4: Control complete digest of 448 bp DNA fragment by EcoRV; Lane 5: Berberine-448 bp fragment complexes digested by EcoRV with berberine concentration of $2 \mathrm{mM}$; Lane 6: palmatine-448 bp fragment complexes digested by EcoRV with palmatine concentration of $2 \mathrm{mM}$.

Adriamycin has been shown to bind to CA with higher affinity than GC rich sequences [2-5], using DNase foot printing assay, transcriptional and restriction inhibition assay. In our study adriamycin shows a complete inhibition for Hindlll activity at $100 \mu \mathrm{M}$ concentration and binds to GC rich sequences, which supports the sequence and structural studies done by a few authors using $x$-ray [7] and NMR [9] methods and this shows that it intercalates between CG base pair. Our results also support daunomycin affinity for GC containing sequence by $100 \%$ inhibition of Hindlll activity at $100 \mu \mathrm{M}$ concentration. This result is in accordance with binding studies of daunomycin by foot printing and restriction inhibition assay [5], which showed preference of daunomycin for
GC base pair flanked by AT base pair. Therefore RIA can provide sequence specificity for these standard drugs used in this study. Structural studies of daunomycin complexed with DNA using $\mathrm{x}$-ray method showed that it intercalates between CG base pair [8]. There are no conclusive reports available regarding structure and conformation of mitoxantrone complexed to DNA. Therefore there is a need for the sequence specificity of mitoxantrone, berberine and palmatine. In this context Fig 4, shows a typical restriction inhibition assay gel for mitoxantrone including a control-the 448 bp DNA fragment without drug. As the concentration of mitoxantrone was increased (lanes 2-6) the intensity of the digested fragments decreased gradually.

Finally, $100 \%$ inhibition in restriction was achieved at $220 \mu \mathrm{m}$ (lane 4), when compared to the control (lane 1). This result throws an insight on the mitoxantrone specificity for 5'GC-3'. This result supports the studies by Fox et al [1] and Panousis et al [3] using in vitro transcription assay and DNase foot printing assay, respectively. These assays show sequence specificity towards CG, CA and TA (reading in the 5'-3' direction). Figure 5 shows RIA assay gel of berberine and palmatine with EcoRI and EcoRV. Both palmatine and berberine did not demonstrate binding affinities for either EcoRI or EcoRV recognition sequences irrespective of their concentration. Experimentally standardized binding specificity and the binding concentration of distamycin-A, adriamycin, daunomycin, mitoxantrone, berberine and palmatine with the 448 bp DNA fragment are summarized in Table 1.

The specificity for each of the drugs was confirmed by performing a negative control experiment using EcoRI as negative control for drugs like mitoxantrone, adriamycin and daunomycin which bind to Hindlll binding sites, and HindIII as control for drugs like distamycin-A, berberine and palmatine which are known to bind to either 5'-AT-3' or 5'-TA3 ' containing sequences [data not shown]. 
Table 1: A summary of quantitative and qualitative binding data for the anticancer drugs

\begin{tabular}{|c|c|c|c|c|c|}
\hline Drug & $\begin{array}{l}\text { DNA } \\
\text { fragment } \\
\text { length }\end{array}$ & $\begin{array}{l}\text { Binding } \\
\text { concentrations\# }\end{array}$ & $\begin{array}{l}\text { Drugs } \\
\text { sequence } \\
\text { specificity } \\
\text { identified }^{*}\end{array}$ & $\begin{array}{l}\text { Restriction } \\
\text { enzyme } \\
\text { used }\end{array}$ & $\begin{array}{l}\text { Restriction } \\
\text { enzyme } \\
\text { restriction site }\end{array}$ \\
\hline Mitoxantrone & $448 \mathrm{bp}$ & $220 \mathrm{mM}$ & 5'AAGCTT-3' & HindIII & 5'-AAGCTT-3' \\
\hline Adriamycin & $448 \mathrm{bp}$ & $100 \mu \mathrm{M}$ & 5'-AAGCTT-3' & HindIIII & 5'-AAGCTT-3' \\
\hline $\begin{array}{l}\text { Daunomycin } \\
\text { Distamycin A }\end{array}$ & $\begin{array}{l}448 \mathrm{bp} \\
448 \mathrm{bp}\end{array}$ & $\begin{array}{l}100 \mu \mathrm{M} \\
10 \mathrm{mM}\end{array}$ & $\begin{array}{l}\text { 5'-AAGCTT-3' } \\
\text { 5'-GAATTC-3' }\end{array}$ & $\begin{array}{l}\text { HindIII } \\
\text { EcoRI }\end{array}$ & $\begin{array}{l}\text { 5'-AAGCTT-3' } \\
\text { 5'-GAATTC-3' }\end{array}$ \\
\hline Berberine & $448 \mathrm{bp}$ & $\begin{array}{l}\text { No Binding } \\
\text { observed at } 2 \mathrm{mM}\end{array}$ & ------ & $\begin{array}{l}\text { EcoRI \& } \\
\text { EcoRV }\end{array}$ & $\begin{array}{l}\text { 5'-GAATTC-3', } \\
\text { 5'-GATATC-3' }\end{array}$ \\
\hline Palmatine & $448 \mathrm{bp}$ & $\begin{array}{l}\text { No Binding } \\
\text { observed at } 2 \mathrm{mM}\end{array}$ & ---------- & $\begin{array}{l}\text { EcoR I \& } \\
\text { EcoRV }\end{array}$ & $\begin{array}{l}\text { 5'-GAATTC-3' } \\
\text { 5'-GATATC-3' }\end{array}$ \\
\hline
\end{tabular}

\#Concentration of different anti-tumor drugs required to inhibit restriction endonucleases cleavage by $100 \%$.

"Sequence selective binding of different anti-tumor drugs to the 448bp DNA fragment of $p B C K S^{+}$plasmid.

\section{CONCLUSION}

The result of our experiment with distamycinA, adriamycin and daunomycin are similar to those the earlier works. The results obtained with the standards led to successful experimentation with mitoxantrone while the results obtained from restriction inhibition assay of mitoxantrone has shown that binding specificity for '5'-GC-3' is in accordance with that reported by Fox et al [1] and Panousis et al [3], who showed binding at CG, CA and TA (reading in the 5'-3' direction). Berberine and palmatine which were expected to show binding at 5'-ApT-3'or 5'-TpA-3' did not, even at millimolar concentration. Thus, RIA (restriction inhibition assay) is a sensitive and biologically relevant method to determine the binding concentration and sequence specificity of several anti-tumor drugs. Furthermore, this assay can be useful as a screening protocol for determining both sequence specificity and binding concentration of naturally-occurring and synthetic anti-tumor drug candidates. Additionally, this will be a useful tool to study the mechanism of action of several anti-tumor agents at the molecular level.

\section{ACKNOWLEDGMENT}

The authors thank Drs Tejram Sahu and Prabha of School of Biotechnology,
Jawaharlal Nehru University, New Delhi, for their valuable comments.

\section{REFERENCES}

1. Fox KR, Waring MJ, Brown JR, Neidle S. DNA sequence preferences for the anti-cancer drug mitoxanthrone and related anthraquinones revealed by DNase I footprinting. FEBS Lett. 1986; 202(2): 289-294.

2. Skorobogaty A, White RJ, Phillips DR, Reiss JA. Elucidation of the DNA sequence preferences of daunomycin. Drug Des. Deliv. 1988; 3(2): 125-152.

3. Panousis $C$ and Phillips $D R$. DNA sequence specificity of mitoxantrone. Nucl. acids Res. 1994; 22(8): 1342-1345.

4. Trist $H$, Phillips DR. In vitro transcription analysis of the role of flanking sequence on the DNA sequence specificity of Adriamycin. Nucl. Acids Res. 1989; 17(10): 3673-3687.

5. Chaires JB, Fox KR, Herrera JE, Britt $M$, Waring MJ. Site and sequence specificity of the daunomycin-DNA interaction. Biochemistry. 1987; 26(25): 8227-8236.

6. Forrow SM, Lee M, Souhami RL, Hartley JA. The effect of $A T$ and $G C$ sequence specific minor groove-binding agents on restriction endonuclease activity. Chem. Biol. Interact. 1995; 96: 125-142.

7. Frederick $C A$, William $L D$, Ughetto $G$, van der Marel GA, van Boom JH, Rich A, Wanq A H. Structural comparison of anticancer drug-DNA complexes: adriamycin and daunomycin. Biochemistry. 1990; 29: 2538-2549.

8. Quigley GJ, Wang AH, Ughetto $G$, van der Marel $G$, van Boom JH, Rich A. Molecular structure of an anticancer drug-DNA complex: daunomycin plus $d(C p G p T p A p C p G)$.Proc.

Trop J Pharm Res, October2012;11(5):726 
Natl. Acad. Sci. USA. 1980; 77(12): 72047208.

9. Jain $M$, Barthwal SK, Barthwal R, Govil $G$. Restrained molecular dynamics studies on complex of adriamycin with DNA hexamer sequence d-CGATCG. Arch. Biochem. Biophys. 2005; 439: 12-24.

10. Barthwal $R$, Sharma $U$, Srivastava $N$, Jain $M$, Awasthi P, Kaur M, Barthwal S. K, Govil G. Structure of daunomycin complexed to $d$ TGATCA by two-dimensional nuclear magnetic resonance spectroscopy. Eur. J. Med. Chem. 2006; 41: 27-29.

11. Klevit RR, Wemmer DE, Reid BR. 1H NMR studies on the interaction between distamycin $A$ and $a$ symmetrical DNA dodecamer. Biochemistry. 1986; 25: 3296-3303.

12. Pelton JG, Wemmer DE. Structure and dynamics of distamycin $A$ with d(CGCAAATTGGC): d(GCCAATTTGCG) at low drug:DNA ratios. J Am Chem Soc 1990; 112: 1393-1399.

13. Coll $M$, Fredrick $C A$, Wang $A H J$, Rich $A$. A bifurcated hydrogen-bonded conformation in the $d(A . T)$ base pairs of the DNA dodecamer $d$ (CGCAAATTTGCG) and its complex with distamycin. Proc. Natl. Acad. Sci. USA. 1987; 84: 8385-8389.

14. Sambrook J, Russell DW. Molecular cloning: a laboratory manual: New York: Cold Spring Harbor Laboratory Press, 2001; $p 32$. 